\title{
PRZYWÓDZTWO NA POZIOMIE GMINNYM W POLSCE W WARUNKACH KOABITACII - OCZEKIWANIA VERSUS RZECZYWISTOŚĆ
}

\author{
LEADERSHIP AT THE LEVEL OF THE MUNICIPALITY \\ IN POLAND IN TERMS OF COHABITATION: \\ EXPECTATIONS VERSUS REALITY
}

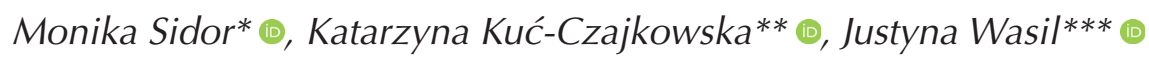

\begin{abstract}
- ABSTRAKT
W artykule podjęto problematykę przywództwa lokalnego w oparciu o badania empiryczne przeprowadzone w latach 2014-2017 wśród wójtów, burmistrzów, prezydentów miast albo ich zastępców, a także radnych, mieszkańców (w tym dziennikarzy, przedsiębiorców, naukowców, przedstawicieli organizacji pozarządowych). W pierwszej części ukazano teoretyczny aspekt przywództwa lokalnego, w drugiej wskazano na uwarunkowania w pełnieniu funkcji wójta (burmistrza, prezydenta miasta), a w trzeciej określono cechy, jakie powinna posiadać osoba pełniąca ten urząd.
\end{abstract}

Słowa kluczowe: lider lokalny; burmistrz; koabitacja; przywództwo; gmina
The article presents the perception of local leadership based on empirical research carried out in 2014-2017 among mayors or their deputies, as well as councilors, residents (including journalists, entrepreneurs, scientists, representatives of non-governmental organizations). The first part shows the theoretical aspect of local leadership, the second indicates conditions in the function of mayor, and the third defines the characteristics required of a person holding this office.

Keywords: local leader; mayor; cohabitation; leadership; municipality

* Uniwersytet Marii Curie-Skłodowskiej w Lublinie, Wydział Politologii i Dziennikarstwa.

** Uniwersytet Marii Curie-Skłodowskiej w Lublinie, Wydział Politologii i Dziennikarstwa.

*** Uniwersytet Marii Curie-Skłodowskiej w Lublinie, Wydział Politologii i Dziennikarstwa. 
Przywództwo polityczne, także to na poziomie lokalnym, jest analizowane pod wieloma względami, m.in. instytucjonalno-prawnym czy indywidualnym (psychologicznym, osobowościowym). Czynniki instytucjonalno-prawne określają m.in. sposób wyłaniania i zakres kompetencji lidera lokalnego, ale także jego funkcjonowania $\mathrm{w}$ otoczeniu wewnętrznym i zewnętrznym. W trakcie sprawowania mandatu jego cechy osobowościowe mogą okazać się istotne dla zbudowania prawidłowych relacji z radą i społecznością lokalną.

W polskiej gminie występuje model silnego przywództwa lokalnego z dominującą pozycją wójta (burmistrza, prezydenta miasta). Jednocześnie to rada gminy ma funkcję uchwałodawczo-kontrolną. Zarówno wójt, jak i radni są wybierani w drodze bezpośrednich wyborów. Istnieje zatem możliwość wyłonienia dwóch organów pochodzących z różnych środowisk politycznych. Współistnienie władz gminnych wywodzących się z różnych obozów politycznych nazwano koabitacją. Po wyborach 2014 r. wystąpiło w blisko 50\% polskich gmin. W tego rodzaju jednostkach mogą wówczas zaistnieć dwa odmienne scenariusze koegzystencji. W pierwszym występuje koabitacja pokojowa - wójt (burmistrz albo prezydent miasta) uzyskuje w trakcie kadencji, pomimo braku większości w radzie bezpośrednio po wyborach, wsparcie wystarczającej liczby (większości) radnych do zarządzania gminą. W drugim zaś przypadku wykształca się koabitacja konfliktowa. Organowi wykonawczemu nie udaje się doprowadzić do koalicji, a relacje $z$ radą gminny są napięte.

W artykule podjęto próbę odpowiedzi na następujące pytania badawcze: Jakie trudności napotyka organ wykonawczy w realizacji swojej funkcji w warunkach koabitacji (w obu wariantach - pokojowym i konfliktowym)? Z czego wynikają trudności w sprawowaniu funkcji wójta (burmistrza, prezydenta miasta) w ocenie samorządowców i lokalnej społeczności? Jakie cechy powinien posiadać włodarz gminy, aby istotnie postrzegany był jako lider lokalny?

W artykule zostały zaprezentowane wyniki badań empirycznych oparte na ponad 70 wywiadach pogłębionych przeprowadzonych w trakcie kadencji 2014-2018 w dwudziestu gminach z koabitacją ${ }^{1}$. Dobór próby był celowy i wynikał z analizy wyników badań ilościowych i jakościowych. Całościowe badanie

1 Badania nad zjawiskiem koabitacji gminnej w Polsce zostały sfinansowane w ramach grantu Narodowego Centrum Nauki OPUS 6, HS5 pt. Koabitacja na poziomie gminnym w Polsce, umowa nr UMO-2013/11/B/HS5/03537. 
składało się z trzech etapów. Pierwszy etap badań polegał na analizie wyników wyborów samorządowych z 2010 i 2014 r. celem wyłonienia województw z największą liczbą gmin, w którym zjawisko koabitacji powtórzyło się w 2010 r. i 2014 r., a także tych, w których wystąpiło ono po raz pierwszy w 2014 r. W drugim etapie badań wysłano 8601 ankiet do 497 gmin w siedmiu województwach, a respondentami byli radni oraz wójtowie, burmistrzowie lub prezydenci miast. Liczba zwrotów wyniosła 1737 ankiet i na ich podstawie zrealizowano trzeci etap badań. W wyniku analizy wypełnionych ankiet, protokołów z sesji obrad rady gminy oraz informacji prasowych zdecydowano, iż wywiady pogłębione zostaną przeprowadzone w 20 gminach. Przy wyborze gmin do wywiadów starano się zachować proporcje pomiędzy gminami: wiejskimi (6), miejsko-wiejskimi (7) i miejskimi (7). Rozmówcami byli zarówno wójt (burmistrz lub prezydent miasta), jak też ich zastępcy, radni oraz mieszkańcy, w tym dziennikarze, przedsiębiorcy, naukowcy, przedstawiciele organizacji pozarządowych.

\section{TEORETYCZNE ASPEKTY PRZYWÓDZTWA}

Powołując się na definicję J. J. Wiatra, przywództwo można określić jako funkcję, która polega na intencjonalnym i permanentnym wpływie jednej osoby na inne. Przywództwo polityczne odróżnia się od innych przez specyfikę grupy, w której zachodzi, i cele, jakie sobie stawia, w tym osiągnięcie władzy. Na poziomie lokalnym występuje tego rodzaju przywództwo. Pozycja przywódcy lokalnego jest jednak nieco inna w porównaniu z poziomem centralnym. Można wskazać na zależność pionową między nimi, ale jest też obecna pewna autonomia działania: elementy samodzielności, inicjatywy i władzy, odpowiedzialność za zbiorowość, oddziaływanie na ludzi (Bartkowski, 1991, s. 10). Jak podkreśla F. Teles (2014), przywództwo jest jednym $z$ najistotniejszych elementów w samorządzie gminnym i składa się z trzech determinantów: świadomości liderów o złożoności i sieciowości kontaktów, niezależności (poczuciu autonomii) i politycznej skuteczności.

Według niektórych badaczy termin lider lokalny nie jest synonimem przywódcy, ponieważ ten drugi wyznacza wizje i określa misję (jest to pojęcie szersze od lidera lokalnego) (Drzonek, 2013, s. 81). Biorąc pod uwagę rozdzielenie omawianych pojęć, warto zastanowić się, czy wójt (burmistrz czy prezydent miasta) jest liderem czy przywódcą. Z jednej strony jest kierownikiem urzędu gminy (miasta), administruje pracą jednostek organizacyjnych i kieruje realizacją 
zadań publicznych, a także wykonywaniem uchwał rady gminy. Z drugiej strony ograniczenie tej funkcji tylko do takiej roli oznaczałoby, że wszystkie samorządy gminne będą funkcjonować $\mathrm{w}$ zbliżony sposób. Tymczasem $\mathrm{z}$ różnego rodzaju analiz i rankingów wynika, że jedni liderzy są bardziej efektywni i posiadają innowacyjne pomysły na rozwój gminy, inni zaś takich wizji nie realizują. W odniesieniu zatem do samorządu lokalnego możemy mówić zarówno o liderze, jak i przywódcy w samorządzie gminnym, stosując te pojęcia zamiennie.

Przedmiotem sporu zapoczątkowanego w polskim samorządzie, jeszcze przed wprowadzeniem bezpośrednich wyborów wójta (burmistrza, prezydenta miasta), pozostaje rola lokalnego włodarza, tzn. kwestia, czy organ wykonawczy powinien być bardziej politykiem czy menadżerem. Jak się wydaje, obydwa wymiary są równie ważne. $\mathrm{W}$ roli lokalnego lidera politycznego przydatne cechy to m.in. umiejętność współpracy, tworzenie koalicji, otwartość na dialog z innymi, kreowanie przyjaznego klimatu dla różnych podmiotów (organizacji pozarządowych, biznesu). Jeśli chodzi o umiejętności menadżerskie, to do pożądanych cech należą m.in.: kierunkowe wykształcenie z zakresu prawa, ekonomii, finansów czy zdolność zarządzania zespołem ludzkim (Lipska, 2008, s. 487-488). E. Bojar (2010), porównując umiejętności menadżerskie i liderskie, wskazuje, że te pierwsze są bardziej techniczne, a drugie twórcze. Menadżer bowiem podąża wyznaczonym schematem, realizuje zadania, jest przezorny, utrzymuje istniejący stan rzeczy, stosuje reguły, skupia się na systemie i strukturze. Natomiast lider znajduje własne rozwiązania, inspiruje, jest innowacyjny, zakłóca równowagę organizacyjną, pomija i tworzy nowe reguły gry, koncentruje się na ludziach. Liderowi należy przypisać takie cechy, jak: entuzjazm, integralność, bycie wymagającym od siebie i innych, uczciwość, ciepło, pokorę, wiarę w siebie (Bojar, 2010, s. 24,33). Jak podkreśla B. Tracy (2010), osobowość przywódcza oznacza osobę mającą zdolność zachęcania innych do realizacji swojej wizji, która opiera się na określonych wartościach i zaletach (np. potrafi ocenić swoje mocne strony). Liderzy mają misję do wypełnienia, potrafią ją sprecyzować i przeformułować na cele (Tracy, 2010, s. 16).

W świetle badań dotyczących przywództwa trudno jednoznacznie powiedzieć, że „przywódcą się trzeba urodzić”. Zależności między przywództwem a danymi cechami osobowościowymi są zaskakująco małe. Można jednak wskazać określone cechy czy umiejętności, które wspomogą efektywne przywództwo. R. M. Stogdill wyróżnił pięć takich ogólnych kategorii: 1) zdolności: inteligencja, trafność oceny, umiejętności werbalne; 2) osiągnięcia: erudycja, wiedza, doświadczenie; 3) odpowiedzialność: wytrwałość, inicjatywa, pewność siebie, pragnienie 
przewyższania innych; 4) uczestnictwo: aktywność, towarzyskość, współpraca, umiejętność adaptacji; 5) status: pozycja społeczna i ekonomiczna, rozpoznawalność (Bodio, Załęski, 2007, s. 383-384).

Z kolei P. John wyróżnił cztery wymiary przywództwa, a jednym z nich jest wymiar psychologiczny, czyli cechy przywódcze konkretnej osoby. Oznacza to, że komponent osobowości włodarza lokalnego ma znaczenie. Ponadto wyróżnił: wymiar prawno-instytucjonalny, czyli prawne umocowanie przywódcy, wymiar systemowo-partyjny, tj. układ i wzajemne relacje partii politycznych na obszarze państwa, oraz wymiar społeczno-kulturowy, czyli kondycję społeczności lokalnej i powiązane z nią oczekiwania wobec lidera (za: Pawłowska 2008, s. 443; Sidor, Kuć-Czajkowska, Wasil 2017, s. 100). Na tej podstawie P. John stworzył klasyfikację przywódców: opiekuńczy, koncyliacyjny, bossowski oraz wizjonerski (za: Swianiewicz, Klimowska, 2003, s. 24-25; Sidor, Kuć-Czajkowska, Wasil, 2017, s. $100-101)$.

Analizując materiał empiryczny z badań nad zjawiskiem koabitacji w Polsce, biorąc pod uwagę zarówno cechy osobowe lokalnego lidera, jak i jego zachowanie w stosunku do otoczenia, stworzono następujące modele przywództwa lokalnego: apodyktyczny administrator, analityczny indywidualista, energiczny wizjoner, niesamodzielny zarządca, żartobliwy lider i ugodowy kierownik (szerzej: Sidor, Kuć-Czajkowska, Wasil, 2017, s. 198-199).

Należy też wskazać, iż nie tylko wymiar indywidualny ma znaczenie w zarządzaniu gminą, ale także wymiar prawno-instytucjonalny, w tym zmiana trendów zachodzących w samorządzie gminnym. Zdaniem P. Swianiewicza, U. Klimowskiej i A. Mielczarka przywództwo na poziomie lokalnym uległo istotnym przeobrażeniom. Jego istotą jest zbudowanie sieci relacji pomiędzy różnymi aktorami, a nie tylko podejmowanie działań opartych na władztwie administracyjnym (za: Drzonek, 2013, s. 83).

Ciekawe postrzeganie przywództwa lokalnego jest również ujęte w koncepcji New Public Management, gdzie przewiduje się korzystanie z rozwiązań biznesowych w administracji publicznej. W ramach NPM założono, że osoby sprawujące funkcje kierownicze realizują pięć nowych ról: architekta konsensusu, popularyzatora spraw lokalnych, interpretatora wartości lokalnych, wzoru etycznego postępowania, współwykonawcy władzy lokalnej (Drzonek, 2013, s. 85).

Uwzględniając wymiar osobowościowy, instytucjonalno-prawny, ale także systemowo-partyjny (za P. John), warto też wskazać, w jaki sposób wyłaniani są kandydaci na liderów lokalnych. Można ich oceniać z perspektywy pragmatycznej i normatywnej. W tej pierwszej preferencje wyborców kierują się ku kandy- 
datowi, który wykazuje się skutecznością w procesie rywalizacji, konkretyzacją potrzeb i interesów społeczności lokalnej.W drugiej perspektywie, normatywnej, istotne dla wyborców są fundamentalne wartości, prawa obywatelskie czy kwestie światopoglądowe. W przypadku liderów lokalnych jest to odwołanie do tożsamości lokalnej, identyfikacja kulturowa, poczucie więzi ze wspólnotą lokalną (Nocoń, 2008, s. 23-24). Istotne jest zatem miejsce urodzenia czy zamieszkania danego kandydata.

Należy również wskazać, jakie trudności może napotkać lider lokalny podczas pełnienia funkcji wójta. Zdaniem S. Michałowskiego sprawowanie lokalnych ról przywódczych wiąże się zarówno z uwarunkowaniami zewnętrznymi (np. funkcjonowanie współczesnych społeczeństw na zasadach decentralizacji i pomocniczości, wprowadzenia do administracji publicznej ekonomicznych wzorców zarządzania) oraz wewnętrznymi (przywiązanie do przywódców, niewielka wiedza mieszkańców o samorządzie terytorialnym) (Michałowski, 2008, s. 28-29, 36). Biorąc pod uwagę te czynniki, a także analizując materiał empiryczny z badań nad zjawiskiem koabitacji, w kolejnej części artykułu wskazano trudności, na jakie napotyka przywódca lokalny w sprawowaniu funkcji/urzędu/władzy.

\section{UWARUNKOWANIA W PEŁNIENIU FUNKCJI PRZYWÓDCY LOKALNEGO - UJĘCIE EMPIRYCZNE}

$\mathrm{Z}$ analizy wywiadów pogłębionych wynika, że pełnienie funkcji wójta nie jest łatwe (wskazała na to przynajmniej jedna osoba w 13 z 20 badanych gmin). Należy zauważyć, iż na odpowiedzi nie miały wpływu relacje między organami władzy i były przywoływane zarówno w gminach z koabitacją konfliktową, jak i pokojową. Jakie zatem trudności napotyka lider lokalny w pełnieniu funkcji/urzędu?

Jednym z czynników, które utrudniają pracę organu wykonawczego jest roszczeniowość społeczności lokalnej przy ograniczonych możliwościach finansowych. Jak stwierdził rozmówca: „To zależy, jeżeli gmina ma pieniądze, to rządzi się o wiele łatwiej. Jeżeli gmina nie ma pieniędzy wcale, to się rządzi strasznie źle. Mieszkańcy nie mogą się z tym pogodzić, że nie ma kasy i żądają wszystkiego" $(Ł 1 w)^{2}$. Podobna wypowiedź była w innej gminie: „Jest to bardzo trudna funkcja. Tym bardziej że ja mogę na przestrzeni lat powiedzieć, że społeczeństwo stało się

\footnotetext{
2 Wywiady są zakodowane w przyjętym jednolitym kluczu znanym autorkom badania, aby zachować anonimowość rozmówców.
} 
bardziej roszczeniowe, zapominając o tym, że każdy mieszkaniec, każdej gminy, jest również zobowiązany do jakiegoś służenia, pomagania sobie nawzajem" (O1w). Zbliżoną opinię miał respondent kolejnej gminy, stwierdzając, że mieszkańcy mają ogromne potrzeby, dodając jednocześnie, że nie należy obiecywać czegoś, co nie jest możliwe do zrealizowania w najbliższym czasie (S3u). Składane obietnice wyborcze muszą być realne z uwzględnieniem możliwości finansowych gminy. Jak podkreślił jeden z włodarzy: „jest to duża odpowiedzialność za mieszkańców, zwłaszcza tych, którzy sobie nie radzą, jednocześnie przy ograniczonym budżecie" (L1w).

Wydaje się, że osobiste poczucie odpowiedzialności za mieszkańców występuje zwłaszcza w mniejszych gminach, ponieważ częstszy i łatwiejszy jest bezpośredni kontakt wójta ze społecznością lokalną. Podkreślił to jeden z rozmówców: „jest to jedna z najtrudniejszych funkcji w ogóle w społeczności lokalnej, tym bardziej że wszyscy w tak małym środowisku znają się. Trudno jest pełnić tę funkcję, bo - wiadomo - znajomi, co drugi, co trzeci przychodzi różne sprawy załatwiać, a to nie można, bo przepisy prawa, a ludzie różnie do tego podchodzą. Z drugiej strony trzeba być człowiekiem otwartym, na ludzi, na rozmowy, dyskusję, na jakieś spotkania. Dużo rzeczy można wyjaśnić, uzgodnić, porozmawiać" (L1u).

Sami badani wskazywali na odmienności, jakie mogą wystąpić w gminach ze względu na ich wielkość i rodzaj. Jeden z mieszkańców podkreślił, iż: „nie jest prosto być prezydentem większego miasta, gdyż im więcej mieszkańców, to więcej oczekiwań, zdań i pomysłów na miasto $(\mathrm{O} 2 \mathrm{o}(2))$. Z kolei inny rozmówca wskazał: nie jest łatwo pełnić funkcję wójta, ale na pewno łatwiej niż w dużych miastach, bo tam są non stop wojny" (O2u). Stwierdzenie to jest powielaniem schematów, które tylko po części odzwierciedlają stan faktyczny. Z badań nad przywództwem lokalnym przeprowadzonych w blisko 30 państwach Europy wynika, że natężenie konfliktów politycznych w polskich gminach nie jest wysokie w porównaniu z tymi europejskimi (najwyższa średnia jest dla Norwegii, Niemiec i części państw Europy Południowej). Konflikt nasila się w zależności od wielkości gminy. Najprostszym uzasadnieniem jest upartyjnienie samorządów miejskich, stąd też występujące podziały ideologiczne i ich konsekwencje (Kopcińska, 2017, s. 26-28).

Podobnie jednak, jak w badaniu nad zjawiskiem koabitacji, partyjność (podłoże ideologiczno-polityczne) nie jest najistotniejszą zmienną, która różnicuje natężenie konfliktu (szerzej: Sidor, Kuć-Czajkowska, Wasil, 2018, s. 129-146). Należy pamiętać, że w gminach, gdzie nie ma przedstawicieli partii parlamen- 
tarnych, powstają quasi-partie popierające określonego lidera politycznego. Ponadto konflikt o podłożu partyjnym występuje tam, gdzie włodarz eksponuje przywiązanie do ugrupowania politycznego. Jak stwierdził jeden z mieszkańców: „animozje takie polityczne tutaj biorą górę. Na ten poziom lokalny też się to przenosi. Tym bardziej że, tak jak mówię, [prezydent jest z konkretnej partii] i tutaj jest namacalne wskazanie. Jest członkiem" [nazwa partii - M.S.] (Ł2o(1)).

W objętych badaniami (wywiadami pogłębionymi) gminach, gdzie występował konflikt pomiędzy organem wykonawczym a radnymi, nie miał on podłoża związanego z przynależnością partyjną. Jeden z rozmówców wskazał: „Część radnych utrudnia pracę burmistrzowi. Albo za bardzo się przejęli tą rolą kontrolną, nazwijmy to, w ten sposób paraliżują też pracę urzędników, o czym niejednokrotnie mówił burmistrz. Bo dostawać 20 pism, które dotyczą jakichś takich drobnych rzeczy, którymi oprócz tej jednej osoby, tego jednego radnego, nikt się nie interesuje, to paraliżuje, bo trzeba odpisać" ( $€ 1 \mathrm{u}(2))$. W innej gminie respondent przyznał, że widoczny był wyraźny podział na radnych koalicyjnych i radnych opozycyjnych: „Radni, którzy są przychylni burmistrzowi, dzielą się tymi pomysłami. Radni opozycyjni się nimi nie dzielą, ponieważ wolą to wykorzystywać właśnie jako pewien oręż medialny” (U2w). Można dostrzec pozytywną stronę tego konfliktu, tzn. radni mają pomysł na rozwój gminy i przynajmniej część z nich dzieli się swoimi propozycjami z wójtem.

Należy podkreślić, iż jedną z trudności w sprawowaniu funkcji wójta jest brak merytorycznego wsparcia ze strony radnych. Zdaniem przedstawiciela mieszkańców uczestniczącego w badaniu: „nie ma w tej radzie opozycji, która byłaby merytoryczna, pomysły, które są zgłaszane, nawet jeśli co do idei są słuszne, to zazwyczaj nie mają oparcia w budżecie, w możliwościach finansowych” (Ł2o(2)). Inny rozmówca podkreśla: „Niektóre rzeczy są trochę na wyrost, bo nie do końca ci nowi radni rozumieją prawidła działania, funkcjonowania budżetu, czyli można powiedzieć tej księgowości budżetowej" (O1w). Z kolei w innej społeczności wskazano: Nie realizuje [organ wykonawczy - M.S.] „pomysłów radnych, bo oni ich nie mają, miałka opozycja” (S1o(1)). Nie zawsze jednak to radni są niekompetentni. Istotną przeszkodą w pełnieniu funkcji wójta jest też brak doświadczenia samorządowego samego włodarza gminy (o czym w trzeciej części artykułu).

Wśród innych czynników, które wpływają na postrzeganie funkcji wójta (burmistrza, prezydenta) jako trudnej, jest liczba zadań samorządowych, co potwierdzają cytaty: „materia jest szeroka (W1o), dużo reform i trzeba się w tym wszystkim odnaleźć" (O1o). Zmiany systemu wyborczego również wpłynęły 
niekorzystnie na część gmin: „Nasze nieszczęście polega na tym, że są okręgi jednomandatowe, wszystko skupia się wokół ulicy, z której startują" [radni M.S.] (Ł3w).

W odniesieniu do liderów lokalnych w innych europejskich państwach, polscy wójtowie, burmistrzowie, prezydenci są obciążeni nadmierną liczbą obowiązków ceremonialno-reprezentacyjnych (Krukowska, 2017a, s. 24). Jest to również przyczyna postrzegania funkcji organu wykonawczego przez respondentów jako trudnej i wymagającej. Nie wymogi formalne, a względy zwyczajowe sprawiają zatem, że organ wykonawczy jest zmuszony uczestniczyć w różnego rodzaju uroczystościach i „przecinać wstęgę” ( $\mathrm{S} 2 \mathrm{o}(1))$. Jeden z rozmówców podkreślił, iż: „jest to w pewien sposób funkcja wymagająca, ponieważ wielość spotkań, wiadomo, że jest to czas pracy nienormowany, nie przekłada się na dość prosty stosunek pracy, tylko jest to dość wyczerpujące, aczkolwiek dla ludzi lubiących wyzwania bardzo fajne doświadczenie i kwestia jest tego, czy ktoś to lubi czy nie” (Ł3u). Podobnie inny rozmówca wskazuje na: „nienormowany czas pracy, samodyscyplinę, konsekwencję, świetną organizację" (L2u(1)).

Przy ocenie trudności sprawowania funkcji wójta (burmistrza, prezydenta miasta) pojawiły się też wypowiedzi wskazujące na postrzeganie tej funkcji w zależności od wielkości gminy. Jak zauważył jeden z rozmówców, nie jest trudno administrować gminą składającą się z 3 tys. mieszkańców ( $€ 4 w)$.W takich małych gminach problemem są przede wszystkim finanse: „W małej gminie są plusy i minusy bo jest mały budżet, większe gminy mają większy budżet (...). Różnego rodzaju problemy pojawiają się: utrzymanie dróg, odśnieżanie, zadbanie o rowy i w takiej małej gminie szuka się tych środków zewnętrznych, dlatego potrzebny jest dobry menadżer” (Ł4u(1)). Bezpośredni sposób wyboru organu wykonawczego gminy też ułatwia sprawowanie omawianej funkcji. Zdaniem rozmówcy pełnienie roli prezydenta (wójta, burmistrza) jest „łatwiejsze niż kiedyś, bo te bezpośrednie wybory spowodowały, że nie jestem niczyim zakładnikiem. Rada może mieć oczywiście swoją politykę i jak prezydent nie realizował, to go odrzucali i brali innego, by realizował potrzeby większości. Dzisiaj tak nie ma, (a) wybory są jedynym takim sprawdzianem i oceną działalności prezydenta” (S1w).

Dla wielu rozmówców (jak wynika z przeprowadzonych badań) rola lidera lokalnego przypisywana do osoby wójta (burmistrza, prezydenta) jest determinowana przez roszczeniową postawę części mieszkańców czy niewystarczające środki finansowe w budżecie gminy. Trzeba też pamiętać, że w danej gminie organ wykonawczy może być jednym z nielicznych politycznych liderów posiadających kompetencje i predyspozycje do zarządzania jednostką samorządu 
terytorialnego, a radni w niewielkim stopniu ( $\mathrm{z}$ różnych względów) wspierają taką osobę merytorycznie. Brak pomocy ze strony rady gminy (radnych) może być też wynikiem konfliktu pomiędzy organami władzy. Aspekty osobowościowe lidera mają wówczas istotne znaczenie, szczególnie w sytuacji nieprzychylnego nastawienia części radnych. Warto zatem przyjrzeć się cechom pożądanym, które powinien posiadać przywódca lokalny, aby skutecznie zarządzać gminą.

\section{CECHY PRZYWÓDCY LOKALNEGO - UJĘCIE EMPIRYCZNE}

Jak wskazano, analizując kwestię przywództwa, bierze się pod uwagę m.in. wymiar psychologiczny, czyli cechy lidera lokalnego. W przeprowadzonym badaniu nad zjawiskiem koabitacji zapytano rozmówców (również wójtów, burmistrzów, prezydentów miast), jakie cechy powinien posiadać organ wykonawczy, aby dobrze zarządzać gminą. Warto dodać, iż funkcji publicznej, jaką jest urząd wójta, towarzyszy też kreowanie wizerunku, który nie zawsze jest zgodny z tym, jak postrzega siebie osoba pełniąca ten urząd, a jak odbiera go społeczność lokalna. Wizerunek może być zatem: rzeczywisty (jak postrzega danego lidera otoczenie), pożądany (jak chciałby, aby go postrzegano), lustrzany (jak siebie postrzega) oraz optymalny (kompromis, który można osiągnąć z powyższych) (Współpraca z mediami a tworzenie wizerunku organizacji, 2008, s. 9).

W przypadku wykształcenia się w danej gminie koabitacji konfliktowej cechy pożądane u lidera lokalnego, w opinii radnych czy też mieszkańców, nie znajdują przełożenia na rzeczywistą postawę włodarza. Jak stwierdził jeden z mieszkańców: „Wójt kreuje taką otoczkę, że pozostawia wszystko jak gdyby w decyzjach rady. A tak naprawdę, tzn. w sprawach, które są dla niego ważne, dąży do rozstrzygnięcia takiego, jakie proponuje, prawie jak pociąg pancerny, że użyję takiego porównania. Znaczy w kwestiach, które dla niego nie są aż tak istotne, to pozwala im się wypowiadać, głosować, ale w kwestiach zasadniczych - nie. I niestety te kwestie zasadnicze, to są te, które są podszyte jakimiś uprzedzeniami i negatywnym stosunkiem" (W1o). Co ciekawe, w tej gminie wójt postrzega siebie jako osobę elastyczną, potrafiącą dopasować się w danym momencie do zdania większości w radzie. Jak sam twierdzi, jego skuteczność polega na konsekwentnym wyznaczaniu kierunków działania i koncepcji ich realizacji.

Podobny problem wystąpił w innej gminie. Jeden z rozmówców wskazywał na cechy pożądane u wójta: spokój, opanowanie, brak emocji, umiejętność słuchania i dyskusji. Jednocześnie podkreślił, iż w jego gminie sprawująca tę funkcję 
osoba nie ma tych cech i „występuje z pozycji »Kima Korei Północnej« - ja to wiem najlepiej i wy mi nie będziecie mówili, co jest lepiej” (W2u(2)). Sam wójt tej gminy wskazał z kolei, iż w pełnieniu roli organu wykonawczego gminy istotna jest wiedza, umiejętność motywowania i zarządzania ludźmi, zaznaczając dysponowanie takimi atrybutami. Można zatem zauważyć rozbieżność między wizerunkiem pożądanym a lustrzanym.

Zarzut braku wiedzy i doświadczenia wobec radnych ze strony wójta czy odwrotnie: wójta wobec radnych pojawia się zazwyczaj w gminach z koabitacją konfliktową. Działa wówczas „efekt nowicjusza”, tzn. albo rada składa się w większości z radnych pełniących ten mandat po raz pierwszy, albo włodarz jest nowo wybraną osobą, albo też przedstawiciele obydwu organów sprawują tę funkcję/ mandat po raz pierwszy. Dodatkowo w części gmin pojawia się „tęsknota za poprzednikiem”, a wymienione cechy, jak dobre zarządzanie kadrą urzędniczą, umiejętność wypowiedzi, są obarczone stwierdzeniem: poprzednik takie atrybuty posiadał.

Warto podkreślić, że w wypowiedziach odnoszących się do pożądanego stylu zarządzania pojawia się postulat, aby osoba wójta (burmistrza, prezydenta) była „menadżerem, który traktuje gminę jak przedsiębiorstwo” (U2o), czy wskazywano na wykształcenie ekonomiczne. Według badań zespołu projektowego POLLEADER w Polsce, podobnie jak w 19 spośród 28 państw europejskich, ponad połowa włodarzy gmin przed objęciem funkcji pracowała w sektorze publicznym, a ponad $20 \%$ miała za sobą doświadczenie pracy w innych jednostkach samorządu. Z kolei co dziesiąty burmistrz w Polsce był nauczycielem (11,4\% spośród respondentów) (Krukowska, 2017b, s. 16-18).

W badaniach nad koabitacją ustalono, że przynajmniej w trzech spośród dwudziestu gmin włodarz przed objęciem funkcji był nauczycielem (nie wszyscy rozmówcy ujawnili wcześniej wykonywany zawód). Potwierdza to fakt, że - głównie w mniejszych gminach - ta grupa zawodowa cieszy się wciąż dużym poważaniem wśród społeczności lokalnej. Chociaż jeden z respondentów poddawał w wątpliwość, czy zawód nauczyciela jest dobrym punktem wyjścia do pełnienia funkcji organu wykonawczego (U2o).

Jak już wcześniej zaznaczono, w niektórych deklaracjach przywoływano postulat, aby osoba wójta (burmistrza, prezydenta) miała umiejętności menadżerskie: „samorząd to instytucja biznesowa, którą trzeba prowadzić dla dobra mieszkańców" (O3w). Jest to postrzeganie samorządu zgodnie z koncepcją Nowego Zarządzania Publicznego, tzn. przenoszenia mechanizmów zarządzania sektorem prywatnym do zarządzania jednostką samorządu. Inni z kolei 
rozmówcy podkreślali, że włodarz gminy powinien mieć wizję, wsłuchiwać się w głos mieszkańców, być otwarty na komunikację z nimi: obecny [organ wykonawczy - M.S.] „wykazuje brak wizji, brak dialogu, brak komunikacji ze społeczeństwem. Możliwe, że ma jakieś własne spojrzenie na rozwój (...), formalnie, zgodnie z przepisami konsultacje się odbywają, teoretycznie jakaś forma partycypacji społecznej istnieje, natomiast praktycznie partycypacji społecznej nie ma. Głos mieszkańców, organizacji pozarządowych nie jest brany pod uwagę. Jeżeli zapadają jakieś decyzje, są one nieodwołalne, nie podlegają żadnym zmianom. Nie wiadomo czemu. Jest to taki autorytarny system sprawowania urzędu" (W3O(1)). Oczekiwania zatem rozmijają się z rzeczywistością. Otwartość lidera lokalnego na postulaty mieszkańców, a także umożliwienie im współdecydowania o ważniejszych sprawach gminy wiąże się z koncepcją good governance, czyli współzarządzania gminą przez jej mieszkańców.

Jest też grupa badanych, która starała się łączyć powyższe spojrzenie na funkcję egzekutywy w gminie, w tym rolę lidera: „według mnie osoba, która zajmuje stanowisko wójta, burmistrza czy prezydenta miasta, generalnie powinna odznaczać się taką charyzmą i cechami przywódczymi, które pozwolą na kierowanie dużym zespołem osób w związku z zajmowaną funkcją szefa urzędu, ale również powinna posiadać kompetencje, które pozwolą odnajdywać się w różnych sytuacjach życiowych, czyli zarówno takiego twardego negocjatora, jak również osoby, która czuje empatię" (W3o(3)). Kolejny mieszkaniec wskazywał: „Prezydent powinien być reprezentantem inicjatywy oddolnej, powinien być społecznikiem, a przede wszystkim działać w interesie miasta i mieszkańców" $(\operatorname{S} 1 \mathrm{o}(2))$.

Z wywiadów wynika, iż oczekiwania wobec osoby włodarza gminy są bardzo szerokie. Powinna to być osoba $\mathrm{z}$ umiejętnościami menadżerskimi, komunikatywna, dążąca do kompromisu, z szeroką wiedzą samorządową, z wizją rozwoju gminy. W dużych miastach pojawiły się też wymagania co do korzystania $\mathrm{z}$ narzędzi partycypacji społecznej, a także umiejętności łączenia potrzeb różnych grup interesów. Natomiast w gminach miejsko-wiejskich i wiejskich postulowano, aby przywódca wsłuchiwał się w głos mieszkańców, wyróżniał się empatią i miał czas na komunikację bezpośrednią. Jednocześnie lokalny lider powinien być asertywny, gdyż nie każde żądania czy potrzeby mieszkańców można spełnić. Zwracano też uwagę na „wytrzymałość psychiczną” (Ł4w), „dużą odporność na stres” (W2o), „odporność na krytykę zewnętrzną” (U2u), „trzeba być człowiekiem bardzo twardym, często bezkompromisowym” (L3w). Jak stwierdził jeden z rozmówców: „Ważną cechą, moim przynajmniej zdaniem, jest «gruba 
skóra», bo dość często się obrywa za różne rzeczy. Trzeba więc mieć taką łatwość w kontaktach z mieszkańcami. Takie opanowanie" (U1o). Analizując te wypowiedzi, należy stwierdzić, iż częściej tego typu cechę - „odporność psychiczną” wymieniano w gminach z koabitacją konfliktową (w 4 przypadkach), aczkolwiek wskazywano na nią również we wspólnotach lokalnych z koabitacją pokojową (w 3 przypadkach).

Atrybutem osoby wójta powinna też być umiejętność opanowania emocji i ich rozładowania: „Duży spokój na pewno, akurat ten nasz trochę ma poczucie humoru i to wykorzystuje czasem na komisjach, na sesjach, rozładowując atmosferę. To jest myślę (dobre) akurat w takiej sytuacji jak u nas, gdzie rada to większość jego przeciwników" (Ł1u(3)). Co ciekawe, jeden z rozmówców podkreślił (zdając sobie sprawę, że takiej cechy nie posiada), że jest przydatna: „Czasami trzeba się ugryźć w język, człowiek chce powiedzieć prosto z mostu człowiekowi, to nie może" (U1w). Na brak takiej umiejętności u wójta tej gminy wskazywał inny rozmówca: „ale oprócz chęci i wiedzy potrzebna jest dyplomacja, bo niekiedy dyplomacją uzyskuje się dość dużo. Podejście do radnych i nawet podejście do tych ludzi ze wsi, że tak powiem, podejściem dyplomatycznym więcej się zdziała niż powiedzieć: ja tu rządzę i wy macie mnie słuchać” (U1u).

Wydaje się, że osoba, która pełni funkcję wójta (burmistrza, prezydenta), oprócz cech nabytych może kształtować swój wizerunek tak, aby był optymalny - zgodny z wewnętrznym postrzeganiem siebie i zewnętrznymi oczekiwaniami wobec lidera lokalnego. Potrzebna jest pokora i dystans do siebie.

\section{PODSUMOWANIE}

Pełnienie funkcji organu wykonawczego gminy wiąże się z określonymi oczekiwaniami wobec osoby na takim stanowisku. Powinna się wykazywać umiejętnościami i cechami ułatwiającymi zarządzanie gminą. W artykule skupiono się na wymiarze instytucjonalnym i psychologicznym (indywidualnym, osobowościowym) przywództwa lokalnego. W wymiarze instytucjonalnym wskazano, na jakie rzeczywiste trudności napotyka lider lokalny podczas pełnienia swojej funkcji w warunkach koabitacji. Są to m.in. roszczeniowa postawa społeczności lokalnej przy ograniczonym budżecie gminy, konflikt z radnymi (w gminach z koabitacją konfliktową) i brak merytorycznego wsparcia ze strony rady. Omawiane trudności można za S. Michałowskim nazwać uwarunkowaniami wewnętrznymi. Z kolei do trudności zewnętrznych zaliczyć należy: dużą liczbę 
zadań nałożonych na samorząd gminny, nienormowany czas pracy i obciążenia obowiązkami ceremonialno-reprezentacyjnymi. Wszystko to sprawia, że funkcja wójta (burmistrza, prezydenta miasta) jest postrzegana jako trudna. Jednocześnie poprzez wprowadzenie bezpośredniego sposobu wyboru lider lokalny otrzymał pewną autonomię i ma swobodę w kształtowaniu polityki gminnej. Posiadanie wizji, kreatywność to cechy skutecznego przywódcy lokalnego. W wymiarze psychologicznym zauważyć można, iż w gminach z koabitacją konfliktową wizerunek rzeczywisty jest rozbieżny z pożądanym wizerunkiem lidera. Spektrum oczekiwań wobec osoby na tym stanowisku jest bardzo szerokie - od wskazania pożądanego wykształcenia do postulatu o empatię i umiejętność wsłuchania się w głos mieszkańców.

Daje się wyodrębnić różnice w oczekiwaniach wobec organu wykonawczego ze względu na rodzaj gminy. W miastach spodziewano się większej otwartości wobec działań mieszkańców (zgodnie z koncepcją współrządzenia), a w gminach wiejskich i miejsko-wiejskich postulowano otwartość i czas na dialog z mieszkańcami oraz wrażliwość na ich potrzeby. Ważną cechą, umiejętnością włodarza lokalnego - jak się wydaje - jest świadomość własnych słabości i pokora. W ten sposób lider lokalny osiąga spójność w postrzeganiu siebie i autentyczność wobec otoczenia. Wizerunek optymalny to istotne osiągnięcie w przypadku osoby przywódcy lokalnego, gdyż oczekiwania nie rozmijają się z rzeczywistością.

\section{BibLIOGRAFIA:}

Bartkowski, J. (1991). Kariery działaczy lokalnych: systemowe mechanizmy selekcji w latach osiemdziesiątych. Warszawa: Instytut Socjologii UW.

Bodio, T., Załęski, P. (2007). Przywództwo i elity polityczne, W: K. A. Wojtaszczyk, W. Jakubowski (red.). Społeczeństwo i polityka. Podstawy nauk politycznych (s. 383398). Warszawa: Wydawnictwo Aspra.

Bojar, E., Rakowska, A., Zarębska A., Bojar M. (2010). Przywództwo w zarządzaniu rozwojem lokalnym. Białystok: Białostocka Fundacja Kształcenia Kadr.

Drzonek, M. (2013). Reelekcje prezydentów miast w wyborach bezpośrednich w Polsce. Kraków: Wydawnictwo Dante.

Kopcińska, M. (2017). Konsensus czy konflikt polityczny w europejskich gminach. Wspólnota.

Krukowska, J. (2017a). Bez współpracy ani rusz. Wspólnota.

Krukowska, J. (2017b). Skąd się biorą burmistrzowie. Wspólnota.

Lipska, A. (2008). Wójt, burmistrz, prezydent - lokalni liderzy polityczni czy menadżerowie? W: S. Michałowski, K. Kuć-Czajkowska (red.). Przywództwo lokalne a ksztaltowanie demokracji partycypacyjnej (s. 481-489). Lublin: Uniwersytet Marii Curie-Skłodowskiej. 
Michałowski, S. (2008). Uwarunkowania pełnienia ról przywódczych w samorządzie terytorialnym. W: S. Michałowski, K. Kuć-Czajkowska (red.). Przywództwo lokalne a kształtowanie demokracji partycypacyjnej (s. 27-44). Lublin: Uniwersytet Marii Curie-Skłodowskiej.

Nocoń, J. (2008). Kryteria wyłaniania lokalnych liderów politycznych. W: S. Michałowski, K. Kuć-Czajkowska (red.). Przywództwo lokalne a kształtowanie demokracji partycypacyjnej (s. 13-26). Lublin: Uniwersytet Marii Curie-Skłodowskiej.

Pawłowska, A. (2008). Prawno-instytucjonalny wymiar przywództwa lokalnego (na przykładzie wybranych państw). W: A. K. Piasecki (red.). Model przywództwa (s. 442-465), Kraków: Wydawnictwo Profesja.

Sidor, M., Kuć-Czajkowska, K., Wasil, J. (2018). (Bez)partyjne podłoże koabitacji konfliktowej w polskich gminach. W: K. Kamińska-Karolczuk, M. Mielewczyk, R. Ożarowski (red.). Meandry współczesnego systemu partyjnego w Polsce (s. 129-146). Gdańsk: Wydawnictwo Athenae Gedanenses.

Sidor, M., Kuć-Czajkowska, K., Wasil, J. (2017). Koabitacja na poziomie gminnym $w$ Polsce. Warszawa: Wydawnictwo Scholar.

Swianiewicz, P., Klimowska, U. (2003). Kto rządzi gminą i jak? Lokalni liderzy polityczni w teorii i praktyce samorządów w Polsce. Studia Regionalne i Lokalne, 4(14), 15-40.

Teles, F. (2014). Facilitative Mayors in Complex Environments: why political will matters. Local Government Studies, 40(5), 809-829.

Tracy, B., Scheelen F. M. (2010). Osobowość lidera. Warszawa: Wydawnictwo Studio EMKA.

Współpraca z mediami a tworzenie wizerunku organizacji (2008). Pakiet Edukacyjny Pozaformalnej Akademii Jakości Projektu cz. 3, oprac. Fundacja Rozwoju Systemu Edukacji, Narodowa Agencja Programu „Młodzież w działaniu”. 